\title{
Charcot: Buddhist Leanings?
}

\author{
Hélio A.G. Teive ${ }^{a, b}$ Carlos Henrique F. Camargo ${ }^{b}$ Olivier Walusinski ${ }^{c}$ \\ Andrew J. Lees ${ }^{d}$ \\ aNeurology Service, Internal Medicine Department, Hospital de Clínicas, Federal University of Paraná, Curitiba, \\ Brazil; beurological Diseases Group, Postgraduate Program of Internal Medicine, Hospital de Clínicas, Federal \\ University of Paraná, Curitiba, Brazil; ' Private Physician, Brou, France; ${ }^{d}$ Reta Lila Weston Institute of Neurological \\ Studies, London, UK
}

\section{Keywords}

History $\cdot$ Neurology $\cdot$ Charcot $\cdot$ Religion $\cdot$ Buddhism

\begin{abstract}
Jean-Martin Charcot, considered the father of modern neurology, had a complex personality featuring well-defined characteristics of introversion, competitiveness, irony, and skepticism. While biographers have described him as Republican, anticlerical, and agnostic, the literature also presents evidence that he came to admire Buddhism toward the end of his life; Charcot's involvement with numerous patients suffering from incurable and insidious neurological diseases may have contributed to this change in attitude.
\end{abstract}

(c) 2021 S. Karger AG, Basel

\section{Introduction}

Jean-Martin Charcot (1825-1893; Fig. 1), who is known as the founder of modern neurology, was the most influential researcher in this field during the nineteenth century [1-6]. He made numerous contributions to med- icine in general, neuropathology, and neurology, notably the clinical and pathological definition of amyotrophic lateral sclerosis, multiple sclerosis, a hereditary sensorymotor neuropathy known as Charcot-Marie-Tooth disease, he helped to define Parkinson's disease and conducted studies on hysteria [1-3, 7-11]. Charcot's personality has been addressed in detail: complex and secret, shy, tyrannical, and ambitious, while also taciturn and occasionally ironic and sarcastic. His literary, musical, and artistic abilities were also well known, along with his dedication to work and his family and a great love for animals $[1,2,12-21]$. Little is known about his political and religious preferences, as there are no indications of his engagement in either area. Existing biographical work suggests he was Republican and anticlerical, without any religious stance; to paraphrase Poirier, "Pour moi, il y a un dieu, mais lointain, très vague, Charcot l'aurait dit!" ["For me, there is a god, but distant, very vague, Charcot would have said!'] [12].

However, particularly during his last decade of life, Charcot apparently approached ideas common to Buddhism [12]. This article reviews Charcot's relationship with Buddhism. 


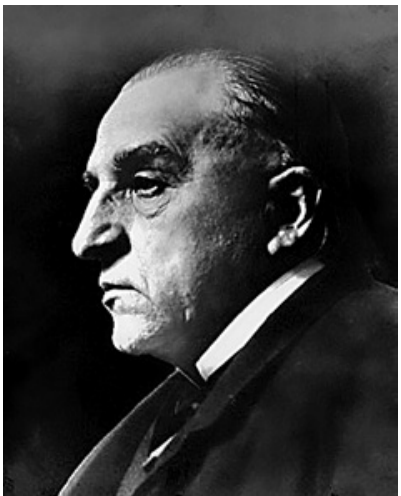

Fig. 1. Professor Jean-Martin Charcot (1825-1893) (Extracted from Google images: Commons; Wikimedia.org, November 2020).

\section{His Hard Life of a Doctor Influenced His Religion's Concept}

Charcot's biographers describe a clinical scientist with an obsessive-compulsive personality profile, who was consequently fascinated by the study of neurological disorders, particularly neurodegenerative diseases (e.g., "Charcot: the discoverer of diseases") [1-4, 7-9, 12, 22]. Throughout his academic career, the more than 3 decades he spent at the Salpêtrière Hospital, "the great asylum for human misery," and during his correlation of detailed clinical data on his patients and findings from neuropathology and anatomical examinations, he did not demonstrate any religious inclinations in his daily life $[1,2,12-14,23]$. Interestingly, although, a year before his death, Charcot wrote a book entitled La foi qui guérit [Faith Healing] [24]. In it, he discussed cases of miraculous cures with an emphasis on the most common associated factors, such as functional disorders (e.g., hysteria), where the mind's influence on the body and the power of self-suggestion could lead to a cure [24, 25]. Except for this book, Charcot did not leave any diaries which are known or even memoirs. Descriptions of the suffering he saw in his patients can be found in letters he wrote to friends and family [12]. As Charcot built his vast clinical experience, evaluating patients with various neurodegenerative diseases and observing their poor clinical progress and early death without any treatment options, he became much more "silent and meditative," expressing skepticism and a cold and pessimistic attitude [1, 2, 12-17]. After examining a patient with amyotrophic lateral sclerosis, he stated, "the prognosis is deplorable, alas, he is a lost soul and it is only a question of time." The fa- mous biography of Charcot written by Goetz et al. [1], describes the phrases he inscribed on the walls of his summer house in Neuilly, words by Shakespeare that defined the vanity of the world and the futility of life: "As flies to wanton boys, are we to the gods. They kill us for their sport." On another occasion, in discussing heredodegenerative diseases, he exclaimed, "What have we done, oh Zeus! To deserve this destiny? Our fathers were wanting, but we, what have we done?" However, he was also able to quote Shakespeare in a more positive and meditative way: "There are more things in heaven and Earth than are dreamt of in your philosophy" [2].

\section{Charcot and Buddhism}

The chronic suffering of neurological patients, particularly those facing neurodegenerative and heredodegenerative illnesses, may have caused Charcot to shift away from his formerly agnostic opinions toward an interest in Buddhism, where the central dogma is related to chronic suffering. In the view of Gautama Buddha, the founder of the Buddhist religion, life is characterized by suffering ( $d u k k h a)$, which is the first of the 4 Noble Truths he became aware of when achieving spiritual enlightenment. The truths can be demonstrated in a simpler way as if they were the stages of a medical consultation: (1) dukkha, diagnosis; (2) samudaya, identification of etiology; (3) nirodha, softening and end of suffering; and (4) magga, the correct understanding of the end of suffering [26]. Mentions of Buddhism emerged in letters and statements between Charcot and his closest friends [12]. One was found in the transcription of letters Charcot exchanged with his friend Philippe Burty (18301890), where he commented: "Je lui avais envoyé une trèês curieuse statuette de Dharma. Il est bouddhiste comme moi." "I had sent him a very curious Dharma statuette. He's a Buddhist - like me."][12, 27]. In another, Léon Daudet, a close friend of the Charcot family, wrote "...Il croyait que... les mystères de la religion catholique sont des sottises.... Ce savant, auréolé, de son vivant, d'une autorité telle et si tyrannique que personne n'osait le contredire. Par contre, il se déclarait plein de vénération pour le bouddhisme." ["He believed that.... the mysteries of the Catholic religion are nonsense.... This scholar, haloed during his lifetime, with such and tyrannical authority that no one dared to contradict him. On the other hand, he declared himself full of veneration for Buddhism"] [12, 28]. 


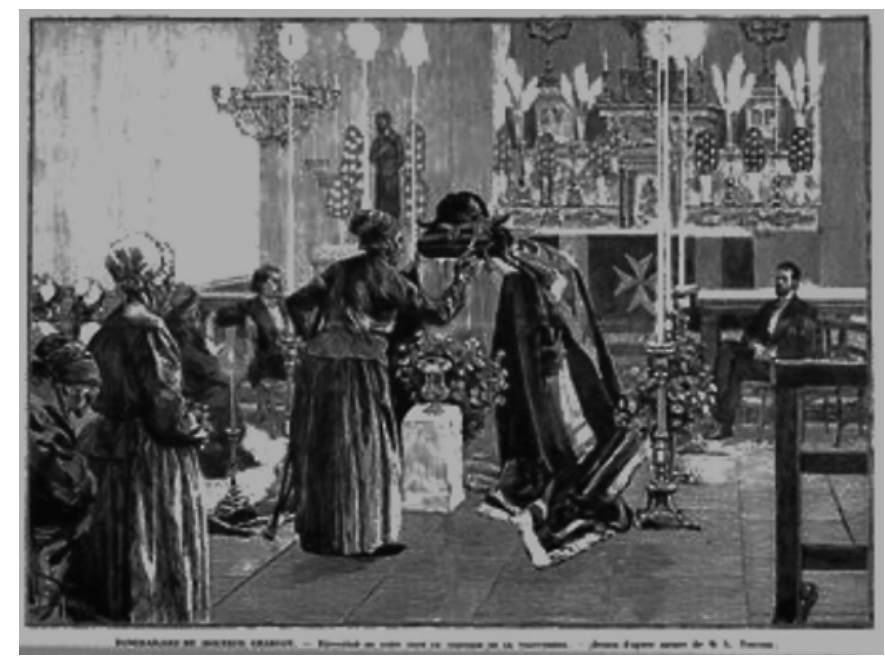

Fig. 2. Charcot's funeral in the catholic chapel of the Salpêtrière Hospital (From Dr. Walusinski archives).

Similar statements were also made by the French writer Léon Bloy (1846-1917), and Charcot's son, Jean-Baptiste Charcot (1867-1936), who was a regular at the salon, held by Madame Helena Petrovna Blavatsky (1831-1891). Blavatsky cofounded the Theosophical Society in 1875 and was important in bringing Buddhism to the West [12, 29]. For Blavatsky [30], Charcot's experiences at the Salpétrière were often unsatisfactorily explained by the materialism of traditional medicine. To the followers of the theosophical philosophy who attended Charcot's presentations of hysteria cases, he seemed like a cold, materialistic scientist. Hypnosis, the use of medical semiology, and treatments should not be interpreted so objectively. There was a mystical side, which Charcot and his pupils did not understand [31]. For them, "science will never read the puzzle of life" [30].

In Buddhism, there is the concept of renaissance, which refers to a process through which beings go through a succession of lives. According to Buddhism, rebirth in subsequent existence should rather be understood as a dynamic continuation, a constant process of change determined by the laws of cause and effect (karma), instead of the notion of being incarnated or transmigrated from one existence to another. Each rebirth occurs within one of the 6 realms. One of them is Tiryak (animals) [26]. Charcot's love of animals would appear to have gone beyond mere professional concern. He is known not to have allowed vivisection or experiments involving animals at Salpêtrière Hospital, and most of his neuroanatomical and neuropathological studies were based on human au-

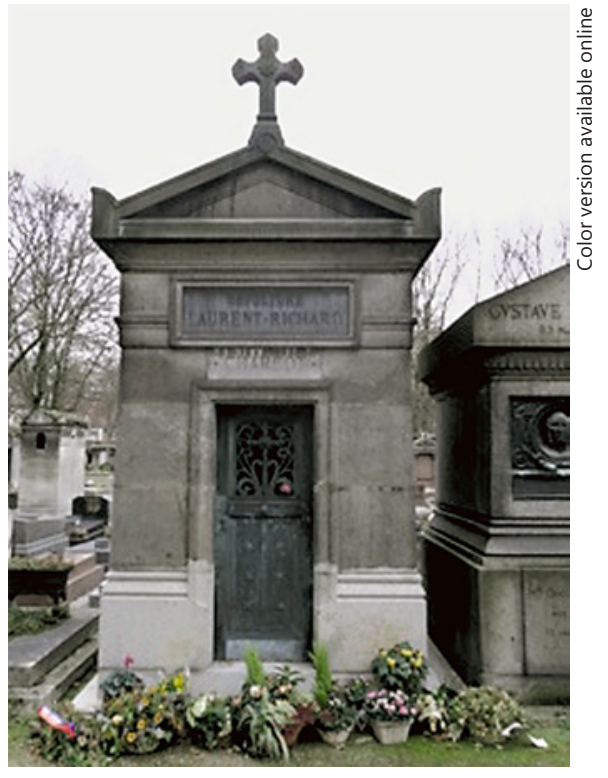

Fig. 3. Charcot's tomb in the cemetery of Montmartre (From Dr. Walusinski archives).

topsies. This attitude contrasted with his great interest in autopsy studies in patients who died at the hospital, which led to the discovery of several neurological diseases $[18$, 21]. How much of this thinking about animals could be due to the influence of Buddhism remains unknown. Buddhist teachings address suffering, impermanence, and the liberation of the mind, and include meditation practices; coincidentally, today meditation is often recommended to treat various illnesses, including some neurological diseases [32-34].

Charcot died on August 16th, in the year of 1893, and paradoxically, he had a funeral in the Catholic rite in the chapel of the Salpêtrière Hospital (Fig. 2). His tomb in the Montmartre cemetery, belonging to the family of his wife of Catholic faith, is surmounted by a cross (Fig. 3). All this by bourgeois convention and probably on his will.

\section{Conclusion}

Some historical documentation suggests that despite Jean-Martin Charcot's well-known anticlerical, republican, and certainly agnostic past, in the final years of his life came to admire Buddhism. This may have been his response to many years of working with countless patients suffering from incurable and progressively fatal neurological diseases. 


\section{Statement of Ethics}

We confirm that approval of an institutional review board was not required for this work. We confirm that we have read the Journal's position on issues involved in ethical publication and affirm that this work is consistent with those guidelines.

\section{Conflict of Interest Statement}

There is no conflict of interest to declare.

\section{Funding Sources}

No targeted funding was reported.

\section{Author Contributions}

1) Project: A. conception, B. organization, C. execution; 2) manuscript: A. writing of the first draft, B. review and critique. Hélio Teive, MD, PhD: 1A, 1B, 1C, and 2A. Carlos Henrique Ferreira Camargo, $\mathrm{MD}, \mathrm{PhD}: 1 \mathrm{C}, 2 \mathrm{~B}$. Olivier Walusinski, $\mathrm{MD}$ : 1C, $2 \mathrm{~B}$. Andrew J. Lees, MD: 1C, 2B.

\section{References}

1 Goetz CG, Bonduelle M, Gelfand T. Charcot: constructing neurology. New York: Oxford University Press; 1995. p. 271-2.

2 Guillain G. JM Charcot: his life-his work. New York: Paul B. Hoeber; 1959. p. 16-29.

3 Goetz CG. Jean-Martin Charcot (1825-1893). J Neurol. 2005;252:374-5.

4 Julien B. Charcot and his legacy. Front Neurol Neurosci. 2014;35:44-55.

5 Jay V. The legacy of Jean-Martin Charcot. Arch Pathol Lab Med. 2000;124(1):10-1.

6 Lennox TA. Jean-Martin Charcot, 18251893. An appreciation. Br J Vener Dis. 1967; 43:77-80.

7 Goetz CG. Chapter 15: Jean-Martin Charcot and the anatomo-clinical method of neurology. Handb Clin Neurol. 2010;95:203-12.

8 Tan SY, Shigaki D. Jean-Martin Charcot (1825-1893): pathologist who shaped modern neurology. Singapore Med J. 2007;48(5): 383-4.

9 Bonduelle M. [Charcot, anatomo-pathologist]. Arch Anat Cytol Pathol. 1994;42(3-4): 171-80.

10 Lellouch A. Jean-Martin Charcot (18251893): a physician with multiple facets. Vesalius. 2013;19(2):60-7.

11 Teive HA, Germiniani FM, Munhoz RP, Paola L. 126 hysterical years: the contribution of Charcot. Arq Neuropsiquiatr. 2014;72(8): 636-9.

12 Poirier J. Jean-Martin Charcot (1825-1893): sa personne, sa personnalité, son personnage. Neuro Lib. 2013;3(Jul-Sep):27.
13 Guinon G. Charcot intime. Paris Med. 1925 Mai;23:511-6.

14 Souques A. Charcot intime. Presse Med. 1925; 42:693-8.

15 Bounduelle M. [The intimate Charcot]. Rev Neurol. 1994;150(8-9):524-8.

16 Teive HA, Munhoz RP, Silva GG. Charcot's skepticism. Arq Neuropsiquiatr. 2012;70(11): 897-9.

17 Teive HAG, Germiniani FMB, Munhoz RP. Charcot's irony and sarcasm. Arq Neuropsiquiatr. 2017;75(6):402-4.

18 Moraes e Silva M, Meira AT, Teive HAG. Charcot's paradox. Arq Neuropsiquiatr. 2019;77(8):590-3.

19 Teive HAG, Arruda WO, Werneck LC. Rosalie. The Brazilian female monkey of Charcot. Arq Neuropsiquiatr. 2005;63(3A):707-8.

20 Teive HA, Almeida SM, Arruda WO, Sá DS, Werneck LC. Charcot and Brazil. Arq Neuropsiquiatr. 2001;59(2A):295-9.

21 Nascimento FA, Camargo CHF, Walusinski $\mathrm{O}$, Teive HAG. Charcot and his passion for dogs: a historical note. Eur Neurol. 2020;11: $1-3$.

22 Lellouch A. [Charcot, discoverer of diseases]. Rev Neurol. 1994;150(8-9):506-10.

23 Walusinski O. Jean-Martin Charcot's house officers at La Salpêtrière Hospital. Front Neurol Neurosci. 2011;29:9-35.

24 Charcot JM. Faith cure. N Rev. 1892;11:24462. [In French: La foi qui guérit. Revue Hebdomadaire. 1892;5:112-132].
25 Lalouette J. Charcot in the center of religious problems of his time. Appropos of "the faith that cures”. Rev Neurol. 1994;150(8-9):5116.

26 Stangroom J. The first Buddhist. Little book of big ideas: religion. London: A \& C Black Publishers; 2007. p. 110-1.

27 Anonymus. Charcot boudhiste. La chronique médicale. 1899;6:31-3.

28 Daudet L. Le stupide dix-neuvième siècle. Paris: Nouvelle Librairie Nationale, 1922.

29 Bloy L. La fin de Don Juan. In Histories désobligeantes. Paris: E dentu, 1890-1899. p. 177.

30 Blavatsky HP. Recent progress in theosophy. North Am Rev. 1890;151(405):173-186. Accessed 2020 December 8. http://www.jstor. org/stable/25102031.

31 Blavatsky HP. Dr. Charcot of Paris (the ilustrious discoverer of the "hysterical cock."). Theosophist. 1880;1(Feb): 127 .

32 Presti DE. Collaborative dialogue between Buddhism and science: a contribution to expanding a science of consciousness. J Comp Neurol. 2020;528(17):2804-15.

33 Rim JI, Ojeda JC, Svob C, Kayser J, Drews E, Kim Y, et al. Current understanding of religion, spirituality, and their neurobiological correlates. Harv Rev Psychiatry. 2019;27(5): 303-16.

34 Kwon CY, Lee B, Chung SY, Kim JW. Do Cochrane reviews reflect the latest evidence on meditation and mindfulness-based interventions? A snapshot of the literature evidence. Explore. 2020;30:S1550-8307. 